This article was downloaded by: [Pinto, A. P.]

On: 19 May 2011

Access details: Access Details: [subscription number 937671738]

Publisher Taylor \& Francis

Informa Ltd Registered in England and Wales Registered Number: 1072954 Registered office: Mortimer House, 3741 Mortimer Street, London W1T 3JH, UK

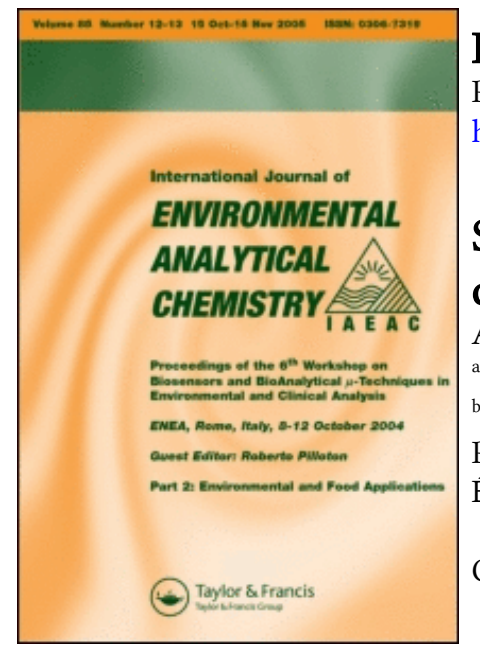

International Journal of Environmental Analytical Chemistry

Publication details, including instructions for authors and subscription information:

http://www.informaworld.com/smpp/title content=t713640455

\title{
Study on the use of Typha spp. for the phytotreatment of water contaminated with ibuprofen
}

Ana Dordio $^{\text {ab }}$; Raquel Ferro ${ }^{\mathrm{a}}$; Dora Teixeira ${ }^{\mathrm{ab}}$; Alfredo J. Palace ${ }^{\mathrm{ac}}$; Ana P. Pinto ${ }^{\mathrm{ab}}$; Cristina M. B. Dias ${ }^{\mathrm{ac}}$ ${ }^{a}$ Departamento de Química, Universidade de Évora, Rua Romão Ramalho 59, 7000-671 Évora, Portugal ${ }^{\text {b }}$ Grupo de Biogeoquimica-IMAR, Universidade de Évora, Rua Romão Ramalho 59, 7000-671 Evora, Portugal ${ }^{\mathrm{c}}$ ICAAM - Instituto de Ciências Agrárias e Ambientais Mediterrânicas, Universidade de Évora, Rua Romão Ramalho 59, 7000-671 Évora, Portugal

Online publication date: 16 May 2011

To cite this Article Dordio, Ana , Ferro, Raquel , Teixeira, Dora , Palace, Alfredo J., Pinto, Ana P. and Dias, Cristina M. B.(2011) 'Study on the use of Typha spp. for the phytotreatment of water contaminated with ibuprofen', International Journal of Environmental Analytical Chemistry, 91: 7, 654 - 667

To link to this Article: DOI: $10.1080 / 03067311003782708$

URL: http://dx.doi.org/10.1080/03067311003782708

\section{PLEASE SCROLL DOWN FOR ARTICLE}

Full terms and conditions of use: http://www.informaworld.com/terms-and-conditions-of-access.pdf

This article may be used for research, teaching and private study purposes. Any substantial or systematic reproduction, re-distribution, re-selling, loan or sub-licensing, systematic supply or distribution in any form to anyone is expressly forbidden.

The publisher does not give any warranty express or implied or make any representation that the contents will be complete or accurate or up to date. The accuracy of any instructions, formulae and drug doses should be independently verified with primary sources. The publisher shall not be liable for any loss, actions, claims, proceedings, demand or costs or damages whatsoever or howsoever caused arising directly or indirectly in connection with or arising out of the use of this material. 


\title{
Study on the use of Typha spp. for the phytotreatment of water contaminated with ibuprofen
}

\author{
Ana Dordio $^{\mathrm{ab} *}$, Raquel Ferro ${ }^{\mathrm{a}}$, Dora Teixeira ${ }^{\mathrm{ab}}$, Alfredo J. Palace ${ }^{\mathrm{ac}}$, \\ Ana P. Pinto ${ }^{\mathrm{ab}}$ and Cristina M.B. Dias ${ }^{\mathrm{ac}}$ \\ ${ }^{a}$ Departamento de Química, Universidade de Évora, Rua Romão Ramalho 59, 7000-671 \\ Évora, Portugal; ${ }^{b}$ Grupo de Biogeoquimica-IMAR, Universidade de Évora, Rua Romão \\ Ramalho 59, 7000-671 Evora, Portugal; ' ICAAM - Instituto de Ciências Agrárias e Ambientais \\ Mediterrânicas, Universidade de Évora, Rua Romão Ramalho 59, 7000-671 Évora, Portugal; \\ ${ }^{d}$ Centro de Química de Évora, Universidade de Évora, Rua Romão Ramalho 59, \\ 7000-671 Évora, Portugal
}

(Received 22 December 2009; final version received 1 March 2010)

\begin{abstract}
Several studies on phytotoxic effects caused by organic xenobiotics and their removal from water by macrophytes have already been performed to evaluate the usefulness of these plants for phytoremediation technologies. In this context, a study was conducted to assess Typha spp.'s ability to withstand and remove, from water, the non-steroidal anti-inflammatory drug ibuprofen. For an initial ibuprofen concentration of $20 \mu \mathrm{g} \mathrm{L}^{-1}$, Typha removed nearly $60 \%$ of it within the first $24 \mathrm{~h}$, attaining over $99 \%$ removal by the end of the assay (21 days). Exposure to higher ibuprofen concentrations did affect Typha's growth but, by the end of the assays, plants' growth as well as photosynthetic pigments approached normal values. An alteration in antioxidant enzymes activities (superoxide dismutase, catalase, guaiacol peroxidase) indicated that both roots and leaves were affected by the xenobiotic. Eventually, Typha seemed able to cope with ibuprofen's induced oxidative damage suggesting its ability for phytotreatment of waters contaminated with ibuprofen.
\end{abstract}

Keywords: constructed wetlands; oxidative stress; pharmaceuticals; phytoremediation; Typha spp.

\section{Introduction}

Contamination of water resources with pharmaceutical residues has been emerging as a major issue in environmental science. Wastewater treatment plants (WWTP) do not guarantee effective removal of pharmaceuticals from wastewaters due to the general inefficiency of the conventional wastewater treatment processes in dealing with this type of compounds, resulting most of the time in the discharge of effluents still contaminated with some pharmaceutical residues [1-3].

One of the pharmaceuticals most frequently found in water resources is ibuprofen (IB) $[1,2]$, a non-steroidal anti-inflammatory drug used in the treatment of rheumatic disorders, pain and fever. This non-prescription drug is among the most consumed pharmaceuticals

*Corresponding author. Email: avbd@uevora.pt 
all over the world and environmental contamination with this substance is a result of the very high inputs of this pharmaceutical into the WWTPs. In fact, despite the sometimes high removal efficiencies of IB in WWTPs (up to 90\%) [1-3], the remaining amounts after treatment still result in the discharge of contaminated effluent.

The foreseeable environmental consequences resulting from the presence of pharmaceuticals in aquatic systems indicates the urgent need for finding cost-effective processes to retain and remove these pollutants before they reach the water bodies.

Phytoremediation technologies such as constructed wetlands (CW) have already been used with success to remove some organic xenobiotic pollutants from wastewaters [4-7]. Such technologies attempt to exploit plants' ability to adsorb, uptake and concentrate or transform organic xenobiotics, as well as to release root exudates that enhance their biotransformation and microbial degradation $[5,6,8]$. However, only very few studies have been carried out recently focusing on the removal of pharmaceuticals by plants $[9,10]$ or in CWs [11-13].

Plants obviously do not have the ability to escape contaminated environments and have evolved mechanisms to deal with the presence of xenobiotics in their systems. Exposure to xenobiotics is a source of abiotic stress which can induce the formation of an excess of reactive oxygen intermediates (ROIs). The potential of these chemical species to damage biomolecules (lipids, proteins, DNA) and ultimately to cause cell death [14] requires the proper response of an antioxidant enzymatic machinery capable of scavenging and eliminating ROIs and maintaining them at a safe level. Activation of enzymes like catalase, superoxide dismutase and peroxidases have been reported for plants subjected to different sources of abiotic stress (drought, excessive light, xenobiotic) [14].

The main goal of this study is the evaluation of the ability of Typha spp. (cattail) to tolerate and remove IB from contaminated water with the purpose of assessing the role of this macrophyte species in the depuration of IB when phytoremediation technologies such as $\mathrm{CW}$ systems are used to treat pharmaceutical contaminated waters. As an important preliminary step, a methodology for the quantification of IB and sample pre-treatment was developed and optimised. In addition, biochemical and physiological parameters were also determined to shed some light on the tolerance mechanisms developed by Typha spp. in the presence of IB.

\section{Experimental}

\subsection{Reagents and materials}

Ibuprofen (IB) (99.8\% purity) was purchased from Sigma-Aldrich (Steinheim, Germany). All other chemicals and solvents were purchased from Sigma-Aldrich (Steinheim, Germany), Merck (Darmstadt, Germany) and Panreac Quimica SA (Barcelona, Spain). Ultra-pure water was obtained with a Milli-Q water purification system (Simplicity ${ }^{\circledR} \mathrm{UV}$, Millipore Corp., France).

Solid phase extraction (SPE) cartridges used were LiChrolut ${ }^{\circledR}$ RP-18 (500 mg, $3 \mathrm{~mL}$ ) from Merck (Darmstadt, Germany), and Sep-Pak ${ }^{\circledR}$ Vac $(500 \mathrm{mg}, 3 \mathrm{~mL})$, Oasis ${ }^{\circledR}$ HLB $(200 \mathrm{mg}, 6 \mathrm{~mL})$ and Oasis ${ }^{\circledR} \mathrm{MCX}(150 \mathrm{mg}, 6 \mathrm{~mL})$, all of which came from Waters Corporation (Milford, MA, USA). Filters with $0.45 \mu \mathrm{m}$ nylon membrane were purchased from VWR International (West Chester, PA, USA). 


\subsection{Quantification of IB in nutrient solutions}

\subsubsection{Sample pre-concentration by solid phase extraction}

Several SPE cartridges were tested with plant nutrient solutions spiked with IB $\left(2 \mathrm{mg} \mathrm{L}^{-1}\right)$ for the choice of the optimal conditions for IB recovery in SPE pre-concentration: LiChrolut $^{\circledR}$ RP-18, Sep-Pak ${ }^{\circledR}$ Vac and Oasis ${ }^{\circledR}$ MCX (all conditioned with $7.5 \mathrm{~mL}$ of methanol and $7.5 \mathrm{~mL}$ of water), and Oasis ${ }^{\circledR}$ HLB (conditioned with $3.0 \mathrm{~mL}$ of methanol and $3.0 \mathrm{~mL}$ of water). After sample $\mathrm{pH}$ adjustment to values of 2, 5 and 7 using either $\mathrm{H}_{3} \mathrm{PO}_{4}$ or $\mathrm{NaOH}$ solutions, the spiked plant nutrient solutions were percolated through the SPE cartridges. The cartridges were then air dried for about 15 min under vacuum to remove excess water. The analyte retained in the cartridges was eluted with $5.0 \mathrm{~mL}$ of methanol. Following elution, the solutions were evaporated on a rotary evaporator at $30^{\circ} \mathrm{C}$ to dryness and redissolved with $1.0 \mathrm{~mL}$ of Milli-Q water. Five replicates were done for every tested cartridge and experimental condition.

Additionally, possible negative effects due to using large sample volumes were evaluated using, according to the results obtained, the best SPE cartridges (LiChrolut ${ }^{\circledR}$ $\mathrm{RP}-18$ ) and conditions ( $\mathrm{pH}$ adjusted to 7). Thus, a series of trials were performed using varying volumes of solution (between $2 \mathrm{~mL}$ and $200 \mathrm{~mL}$ ) adjusted to $\mathrm{pH} 7$ and all containing the same amount of the analyte, which was, at the end, redissolved to a final concentration of $1.0 \mathrm{mg} \mathrm{L}^{-1}$. Three replicates were done of each sample volume assay.

Considering the results obtained, all samples were henceforth prepared by adjusting their $\mathrm{pH}$ to 7 and pre-concentrated in LiChrolut ${ }^{\circledR}$ cartridges.

\subsubsection{Quantification and analytical method validation}

IB in nutrient solutions was quantified by the high performance liquid chromatography (HPLC) technique. Analyses were performed on an Elite LaChrom HPLC system with UV detection (Hitachi, Japan). The reversed phase analytical column used was a Zorbax Eclipse XDB-C18 with $5 \mu \mathrm{m}$ particle size. Chromatographic separation was performed in isocratic mode, and the mobile phase used was composed by $75: 25(\%, \mathrm{v} / \mathrm{v})$ acetonitrile: water, at a flow rate of $1.0 \mathrm{~mL} \mathrm{~min}^{-1}$. Water was acidified with $0.1 \%(\mathrm{v} / \mathrm{v})$ phosphoric acid. The UV detector wavelength was set at $222 \mathrm{~nm}$. Five replicate injections were made for each sample previously filtered through a $0.45 \mu \mathrm{m}$ filter.

Calibration curves were constructed using a set of IB standard solutions with concentrations of $0.25,0.5,1.0,2.0$ and $5.0 \mathrm{mg} \mathrm{L}^{-1}$. Instrumental detection and quantification limits (IDL and IQL) for the chromatographic measurement were obtained by determining the concentrations corresponding to signal-to-noise ratios of 3 and 10 respectively, according to Miller and Miller [15].

The limit of quantification (LOQ) of the entire analytical method (including SPE pre-concentration) was calculated resorting to the following equation [16]:

$$
\mathrm{LOQ}=(\mathrm{IQL} \times 100) /(\operatorname{Rec}(\%) \times C)
$$

where IQL is the instrumental quantification limit $\left(\mathrm{mgL}^{-1}\right), \operatorname{Rec}(\%)$ is the average SPE recovery of IB from the plant nutrient solution and $C$ is the concentration factor (a maximum value of 200 was used).

The reproducibility of the entire analytical method was determined by performing, in different days, quantification of IB recovered from five spiked plant nutrient solutions with different IB concentrations $\left(5-500 \mu \mathrm{g} \mathrm{L}^{-1}\right)$ and sample volumes $(2-200 \mathrm{~mL})$. 
Reproducibility was expressed as the dispersion (relative standard deviation) of IB recoveries.

\subsection{Assay set-up}

\subsubsection{Plants' collection and acclimatisation}

Typha spp. plants were collected in water streams in Alentejo, Portugal, during April 2008. The rhizomes were thoroughly washed to remove any soil/sediment particles attached to the plant surfaces. Plants were then acclimatised and grown in a growth chamber (Fitoclima, Portugal) as described in Dordio et al. [17]. After 6 weeks, when new roots and leaves had developed, plants of uniform size (approximately $30 \mathrm{~cm}$ height) were selected to be used in the assay set-up.

\subsubsection{IB removal assay}

Selected plants, whose roots were rinsed with a dilute hypochlorite solution in order to diminish the native microbial population, were transferred to $3 \mathrm{~L}$ plastic vessels (3 plants per vessel) which contained aerated modified Hoagland nutrient solution with a composition as given in Dordio et al. [17] that was spiked with $20 \mu \mathrm{g} \mathrm{L}^{-1}$ of IB. A control assay, without plants, was set up to evaluate IB photodegradation and the possible effect of IB adsorption on the plastic vessel walls. All assays were done in triplicate. Samples of nutrient solution were collected after $6 \mathrm{~h}, 12 \mathrm{~h}, 18 \mathrm{~h}$ and $24 \mathrm{~h}$ of exposure during the first day, and then every $24 \mathrm{~h}$ during a period of 7 days and, finally, after 14 and 21 days. IB removal by the plants was evaluated along these periods by quantification of remaining IB in the collected samples, following the optimised analytical methodology that had been previously developed.

\subsubsection{Toxicity assays}

A set-up similar to the one just described was used in toxicity assays, but in this case nutrient solutions were spiked with IB at $0.5,1.0$ and $2.0 \mathrm{mg} \mathrm{L}^{-1}$ concentrations, prepared from a stock aqueous solution of $50 \mathrm{mg} \mathrm{L}^{-1}$. Control plants were grown in nutrient solution without IB. For each of the three IB concentrations as well as for the control, three assays were set up corresponding to each one of the three exposure times studied (7, 14 and 21 days), thus making a total of 12 assays. Each assay corresponding to a single exposure time was performed using three replicate vessels. The vessels were arranged as a completely randomised factorial design. At the end of each exposure time the nutrient solution samples were analysed and plants were removed, leaves and roots were separated, immediately frozen in liquid nitrogen and stored at $-80^{\circ} \mathrm{C}$ for posterior analyses.

\subsection{Plant growth parameters}

Fresh-plant weights were measured at different IB exposure times (7, 14 and 21 days) for each of the different initial IB concentrations tested. Visual inspection of injury symptoms was also recorded. Relative growth rates (RGR) were calculated according to the equation:

$$
R G R=\left(\ln W_{1}-\ln W_{0}\right) /\left(t_{1}-t_{0}\right)
$$


where $W_{0}$ and $W_{1}$ are, respectively, the initial and final weights of plants and $\left(t_{1}-t_{0}\right)$ is the duration of the experiment.

\subsection{Chlorophyll and carotenoids contents}

Concentrations of chlorophyll and carotenoids were determined in an $80 \%$ (v/v) aqueous acetone extract using a modified method of Lichtenthaler and Wellburn [18]. Chlorophyll content results are expressed in $\mathrm{mg} \mathrm{g}^{-1}$ of fresh weight (FW) and calculated using extinction coefficients and the equations given by Porra [19]. Carotenoids content results are expressed in $\mathrm{mg} \mathrm{g}^{-1} \mathrm{FW}$ and calculated using extinction coefficients and the equations given by Lichtenthaler and Wellburn [18]. Three replicate measurements were done for each treatment vessel.

\subsection{Activities of antioxidant enzymes}

\subsubsection{Enzyme extraction procedure}

Antioxidant enzymes were extracted from plant tissues following a procedure adapted from Shanker et al. [20]. Plant material, both leaves and roots, $(1.0 \mathrm{~g}$ each from each treatment vessel) was ground to a fine powder in a cold glass mortar with $4.0 \mathrm{~g}$ of acid washed sand and homogenised in $100 \mathrm{mM}$ Tris- $\mathrm{HCl}$ buffer solution $(\mathrm{pH}=7.5)$ containing $1 \mathrm{mM}$ EDTA, $3 \mathrm{mM}$ 1,4-dithiothreitol and $2 \%(\mathrm{w} / \mathrm{v})$ polyvinylpolypyrrolidone. The homogenates were centrifuged at $12,000 \mathrm{~g}$ for 30 minutes at $4{ }^{\circ} \mathrm{C}$ and the resulting supernatants were used for the determinations of the enzymes activities. All steps in the preparation of the enzymes extracts were carried out at $0-4^{\circ} \mathrm{C}$.

\subsubsection{Enzyme activity determination}

Activities of antioxidant enzymes catalase (CAT), superoxide dismutase (SOD) and guaiacol peroxidase (GPX) were measured in roots and leaf tissues of Typha spp. plants exposed to the nutrient solutions spiked with IB, as well as of plants grown in a IB-free nutrient solution for control. CAT activity was measured according to the method of Aebi [21]. The activity of SOD was assayed by the Ferricytochrome $\mathrm{C}$ method using xanthine/xanthine oxidase as the source of superoxide radicals [22]. GPX activity was determined according to the method adopted by Bergmeyer [23].

\subsection{Statistical analysis}

Data were analysed through one-way analysis of variance (ANOVA) for comparison of recoveries obtained by different SPE cartridges and conditions as well as for comparisons of effects due to IB exposure on physiological and biochemical parameters (RGR, photosynthetic pigments and enzymatic activities) with those of the control assays. Comparisons were considered significantly different for $P<0.05$.

\section{Results and discussion}

\subsection{Development and validation of the analytical methodology}

The evaluation of IB removal by Typha spp. requires the use of a chromatographic method for quantification of remaining IB in the plant's nutrient solutions. The HPLC-UV 


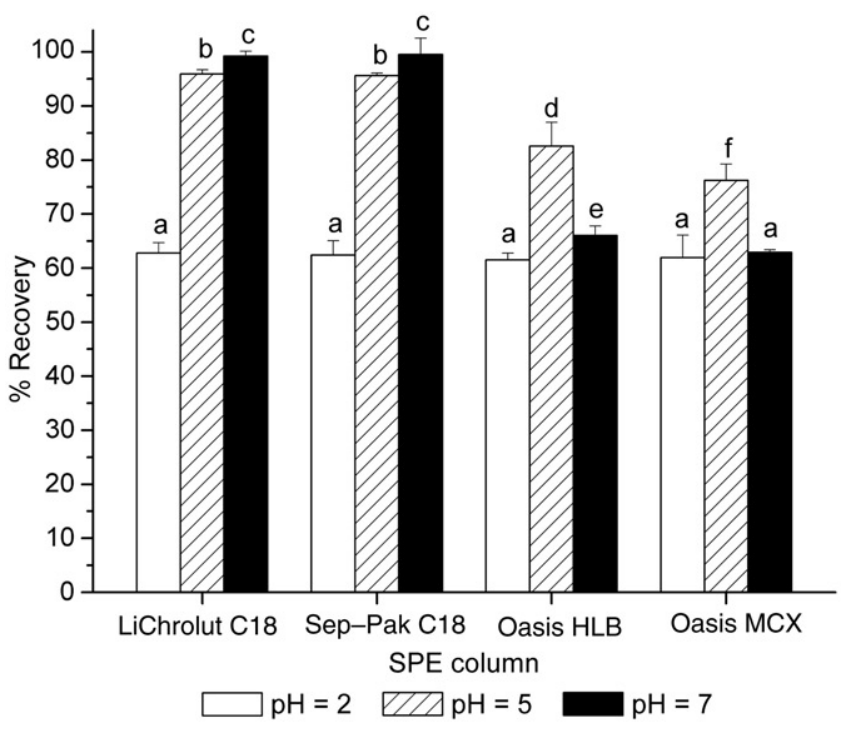

Figure 1. Influence of different SPE materials and $\mathrm{pH}$ adjustment $(2,5$ and 7$)$ on the ibuprofen recovery from plant nutrient solution. Vertical error bars indicate $\pm \mathrm{SD}(n=5)$. ANOVA significant at $P<0.05$ when compared with control. Different letters indicate significantly different values.

technique was used for this purpose. The use of mass spectrometry (MS) detection is sometimes preferred for quantification of trace organics, due to the lower quantification limits, but MS ionisation sources are sometimes susceptible to matrix effects, thus resulting in signal suppression or enhancement and leading to erroneous results [24,25]. On the other hand, coupling the HPLC-UV technique with an appropriate procedure of analyte pre-concentration such as SPE can be used to circumvent the issue with the higher quantification limits of the UV detector [24,25].

Different SPE sorbent materials for performing analyte pre-concentration were thus tested, including a non polar sorbent (LiChrolut ${ }^{\circledR}$ RP-18 and Sep-Pak ${ }^{\circledR}$ Vac), a polymeric sorbent (Oasis ${ }^{\circledR}$ HLB) and a mixed polymeric and cation-exchange sorbent (Oasis ${ }^{\circledR}$ MCX). As shown in Figure 1, the behaviour of the octadecyl-silica based SPE cartridges (C18) was different from the Oasis ${ }^{\circledR}$ polymer cartridges with the first ones yielding better analyte recoveries at higher $\mathrm{pH}$ values and performing equally poorly at the $\mathrm{pH}$ of 2 . The highest IB recoveries were attained with the C18 cartridges with a sample $\mathrm{pH}$ of 7 . Lowering the sample $\mathrm{pH}$ led to lower recoveries for the $\mathrm{C} 18$ cartridges while the best recoveries attained for the Oasis ${ }^{\circledR}$ cartridges was achieved at a sample $\mathrm{pH}$ of 5 , which were nevertheless still lower than those obtained with the $\mathrm{C} 18$ cartridges. This was a somehow unexpected result because previously published results indicate that Oasis ${ }^{\circledR}$ HLB cartridges achieve better yields for the majority of the pharmaceutical residues extracted from water samples, including IB [24,25]. Lowering the sample $\mathrm{pH}$ for the extraction of acidic compounds is not always required and can even have a negative effect in the analytes recoveries, as was also previously observed by Gros et al. [24] for extraction of some pharmaceuticals using Oasis ${ }^{\circledR}$ HLB cartridges.

Taking into consideration the obtained results, LiChrolut ${ }^{\circledR}$ cartridges were chosen to be used throughout this study as this was the least expensive option between the two 
C18 SPE cartridges, given that both yielded essentially the same IB recoveries. For further validation of the SPE procedure, additional tests were performed with the selected cartridge type and using different sample volumes. From these tests it was observed (data not shown) that increasing sample volumes up to a factor of 100 (thereby increasing the amount of salts percolated through the SPE cartridge) has a negligible influence in the IB recoveries.

The detection and quantifications limits of the HPLC-UV methodology used in the IB chromatographic analyses were determined to be $18.0 \mu \mathrm{g} \mathrm{L}^{-1}$ and $60.0 \mu \mathrm{g} \mathrm{L}^{-1}$ respectively, which was too high for the concentration levels tested. However, when coupled with the SPE pre-concentration, the limit of quantification of the entire analytical method, LOQ (as calculated by Equation 1), was found to be $0.3 \mu \mathrm{g} \mathrm{L}^{-1}$, which was low enough for IB quantification in nutrient solutions. The entire analytical methodology was also found to be highly reproducible $(\mathrm{RSD}<1 \%$ ).

\subsection{Ibuprofen removal by Typha}

Typha spp. is an emergent macrophyte which has been frequently used in CWs to depurate water contaminated with organic compounds and has shown a good tolerance when exposed to some xenobiotic substances including some pharmaceuticals $[4,17,26]$. In order to assess its ability to remove IB from contaminated water, an assay was conducted by spiking the nutrient solution with $20 \mu \mathrm{g} \mathrm{L}{ }^{-1}$ of IB, a value which is within the range of IB concentrations detected in the environment $[1,2,27]$ and is typically used in biological removal studies for this kind of pollutant $[11,12]$.

As shown in Figure 2(a), Typha was able to remove nearly all IB present in the nutrient solution. In fact, just within the first $24 \mathrm{~h}$ as much as $58 \%$ of IB was readily removed by the plants and over $95 \%$ after $96 \mathrm{~h}$. By the end of the assay (after 21 days of exposure) IB had been almost completely removed from the nutrient solution ( $>99 \%$ removal). When compared to the removal capacity displayed by Typha for other acidic pharmaceutical compounds [17], IB's removal by this plant species is exceptionally high, suggesting the potential of Typha for removal of this type of compound from water.

IB removal kinetics, as is also shown in Figure 2(a), is characterised by a fast initial stage occurring within the first period of 96 hours, which can be described as a first-order process that fits the equation:

$$
\ln [\mathrm{IB}]_{t}=\ln [\mathrm{IB}]_{0}-0.032 \mathrm{~h}^{-1} t \quad\left(R_{2}=0.994\right)
$$

where $[\mathrm{IB}]_{t}$ and $[\mathrm{IB}]_{0}$ are the IB concentrations $\left(\mu \mathrm{g} \mathrm{L^{-1 }}\right)$ at any given time $(t)$ and at the beginning, respectively.

After $96 \mathrm{~h}$ IB removal proceeds at a much slower rate, the curve in Figure 2(a) being nearly flat beyond this period. A slight increase in removal efficiency (from $95 \%$ to $99 \%$ ) is obtained only if exposure time is extended over a much longer period (up to $504 \mathrm{~h}$ ). This kinetic behaviour is frequently observed in other studies on organic xenobiotics removal by Typha and other plant species [26,28,29]. The kinetic profile of IB removal is very similar to that observed for the removal of another pharmaceutical, clofibric acid, using the same plant species [17] but IB removal progressed at a faster rate.

Xenobiotics removal in hydroponic systems may be attributed to abiotic and biotic processes. However, according to the observations in control assays without plants (where variation of IB concentration in the nutrient solution was negligible for long 

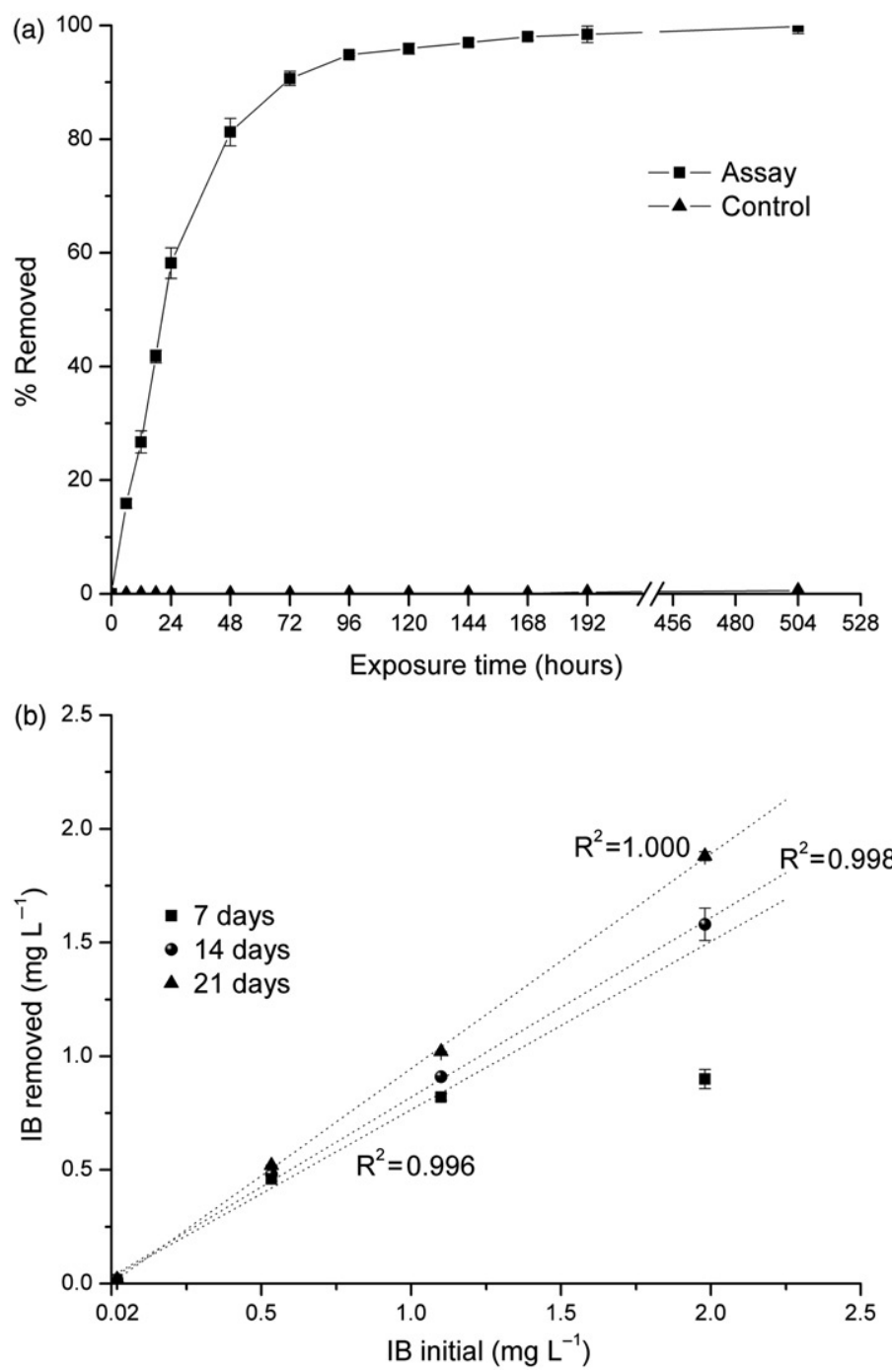

Figure 2. Ibuprofen removal by Typha spp.: (a) percentage removal as function of the exposure time, for an initial concentration of $20 \mu \mathrm{g} \mathrm{L}^{-1}$ and for the control without plants; (b) IB removed after 7, 14 and 21 days versus the initial IB concentration. Error bars represent $\pm \operatorname{SD}(n=9)$.

periods of time, see Figure 2(a)), the influence of abiotic processes such as volatilisation, adsorption to vessel walls, photodegradation and hydrolysis was minimal under the assays conditions. IB removal should, therefore, result mainly from adsorption on the plant rhizomes and from biotic processes such as plant uptake. Microbial degradation should also play an important role under ordinary conditions (and may even be enhanced by rhizostimulation) but, in the current study, care was taken to diminish the microorganisms populations by sterilisation of the roots and materials used. Therefore, microbial degradation should have a very limited contribution in the removal efficiencies reported in these studies, and the system's behaviour can be mainly attributed to the plant's action. 
Synthetic organic compounds like IB are xenobiotic to plants, which do not have specific transporters in their cell membranes for these compounds. Therefore, organic pollutants tend to move into and within the plant tissues driven simply by diffusion, dependent on their chemical properties, especially on their hydrophobicity $[5,6,8]$. Compounds with $\log \mathrm{K}_{\mathrm{ow}}$ between 1 and 3.5 are highly bioavailable to roots of vascular plants such as Typha spp. because they are lipophilic enough to move through the lipid bilayer of membranes, and still water soluble enough to travel into the cell fluids $[5,6]$. IB is a compound that, in its neutral form, is only moderately hydrophobic with a log $\mathrm{K}_{\mathrm{ow}}$ of 2.48 [30]. At higher $\mathrm{pH}$ values this acid is present in its anionic form, which is less hydrophobic (and characterised by a lower $\log \mathrm{K}_{\mathrm{ow}}$ [31]). In this form, IB is potentially taken up and translocated within the plant, where it is accumulated or transformed by the plant's metabolic system.

\subsection{Ibuprofen phytotoxicity}

The exposure to xenobiotics is a cause of abiotic stress which induces an excessive production of reactive oxygen intermediates (ROIs). ROIs are toxic by-products of aerobic metabolism whose enhanced production during stress can be viewed as a cell signal for the activation of stress-response and defense pathways, namely the enzymatic antioxidant system. Measurements of the alterations in key antioxidant enzymes activities in different types of plant tissues may therefore be a useful indication, not only of the plant's reaction to the oxidative stress, but also an evidence for the xenobiotic's translocation within the plant.

In order to assess IB toxicity at increasing concentrations, three new assays were set up using the same conditions tested before but with nutrient solution spiked with IB at concentrations of $0.5,1.0$ and $2.0 \mathrm{mg} \mathrm{L}^{-1}$. These concentrations were chosen following some preliminary assays where the IB concentration level which causes initial visual symptoms of toxicity (e.g. chlorosis) was determined (data not shown). This choice of concentrations range $\left(0.5-2 \mathrm{mg} \mathrm{L}^{-1}\right)$ is slightly below such concentration level and it is expected that plants are consequently under high stress conditions but still do not show any visual toxicity symptoms. In fact, it was observed that these plants were not only able to cope with these large amounts of IB in their nutrient solutions but continued to remove it.

Maximum percentage of IB removal in these high concentration assays ranged from $95 \%$ for the IB initial concentration of $2.0 \mathrm{mg} \mathrm{L}^{-1}$, to $98 \%$ for the assay with IB initial concentration of $0.5 \mathrm{mg} \mathrm{L}^{-1}$ by the end of the assays. When comparing these removals with those of $20 \mu \mathrm{g} \mathrm{L}^{-1}$ assay, they clearly fit a linear relationship between the initial IB concentrations and the IB removed at every corresponding exposure time, with the exception of the values for the 7-day period of exposure for the most concentrated (2.0 $\mathrm{mg} \mathrm{L}^{-1}$ ) IB solution (Figure 2(b)). As will be shown later, the lower IB removal observed is in agreement with the toxicity effects inferred from the plant's lower relative growth rates and the measured enzymatic activity for this period of exposure.

Relative growth rates (RGR) of the plants exposed to the tested concentrations of IB were significantly below those of the control plants after 7 days of exposure and, with exception of the $0.5 \mathrm{mg} \mathrm{L}^{-1}$ assay, were still smaller even after 14 and 21 days of exposure (Figure 3). However, for increasing exposure periods, the RGR of the plants exposed to IB gradually approached the average RGR levels of the control plants 


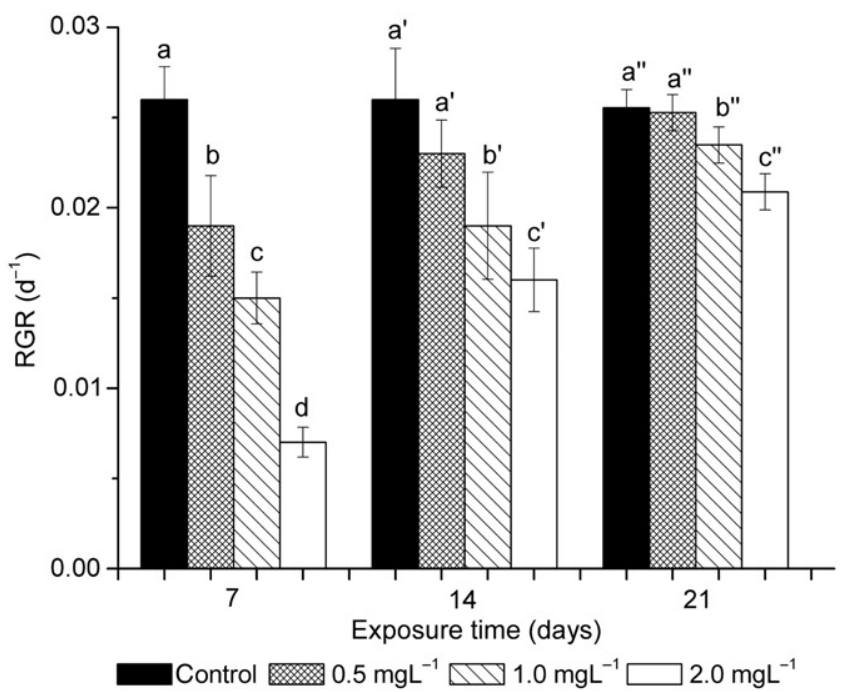

Figure 3. Relative growth rates of plants exposed to IB at concentrations of $0.5,1.0$ and $2.0 \mathrm{mg} \mathrm{L}^{-1}$. Vertical error bars indicate $\pm \mathrm{SD}(n=9)$. ANOVA significant at $P<0.05$ when compared with control. Different letters indicate significantly different values.

Table 1. Average values of photosynthetic pigments contents of Typha spp. after 21 days of exposure to IB $(n=9)$. ANOVA significant at $P<0.05$ when compared to control.

\begin{tabular}{lcccc}
\hline $\begin{array}{l}\text { IB concentration } \\
\left(\mathrm{mg} \mathrm{L}^{-1}\right)\end{array}$ & $\begin{array}{c}\text { Chlorophyll total } \\
\left(\mathrm{mgg}^{-1} \mathrm{FW}\right)\end{array}$ & $\begin{array}{c}\text { Chlorophyll } a \\
\left(\mathrm{mg} \mathrm{g}^{-1} \mathrm{FW}\right)\end{array}$ & $\begin{array}{c}\text { Chlorophyll } b \\
\left(\mathrm{mg} \mathrm{g}^{-1} \mathrm{FW}\right)\end{array}$ & $\begin{array}{c}\text { Carotenoids } \\
\left(\mathrm{mg} \mathrm{g}^{-1} \mathrm{FW}\right)\end{array}$ \\
\hline 0 & $1.6813 \pm 0.0185$ & $1.444 \pm 0.032$ & $0.237 \pm 0.031$ & $0.397 \pm 0.013$ \\
0.5 & $1.6966 \pm 0.0068$ & $1.429 \pm 0.019$ & $0.268 \pm 0.017$ & $0.406 \pm 0.010$ \\
1.0 & $1.6855 \pm 0.0087$ & $1.419 \pm 0.021$ & $0.267 \pm 0.019$ & $0.416 \pm 0.010$ \\
2.0 & $1.2037^{\mathrm{a}} \pm 0.0004$ & $1.314^{\mathrm{a}} \pm 0.009$ & $0.233 \pm 0.011$ & $0.396 \pm 0.005$ \\
\hline
\end{tabular}

${ }^{\mathrm{a}}$ Value with a statistically significant difference from the others in the same coloumn.

that were not exposed to IB. This indicates that the presence of IB does affect the normal plant's growth but plants seem to be able to cope with the toxic effects of this substance because not only do they remove it extensively from the solution (Figure 2(b)) but also they show an evolution towards a recovery to normal growth rates beyond a period of 21 days of exposure (Figure 3).

Chlorophyll (total, $a$ and $b$ ) and carotenoid contents were also determined at the end of the experiments (Table 1). No statistically significant differences were found in the carotenoid and chlorophyll $b$ contents of the plants exposed to IB from those of the control assay. However, for chlorophyll $a$ and total chlorophyll contents, statistically significant differences were observed between the plants exposed to IB concentrations of $2.0 \mathrm{mg} \mathrm{L}^{-1}$ and those of the control assay, whereas the assays at $0.5 \mathrm{mg} \mathrm{L}^{-1}$ and $1.0 \mathrm{mg} \mathrm{L}^{-1}$ of IB remained not statistically different from the control. The lower contents of these pigments in the $2.0 \mathrm{mg} \mathrm{L}^{-1}$ assay may be a sign of toxicity which still subsisted after 21 days of exposure when almost all the IB had been removed from solution. 

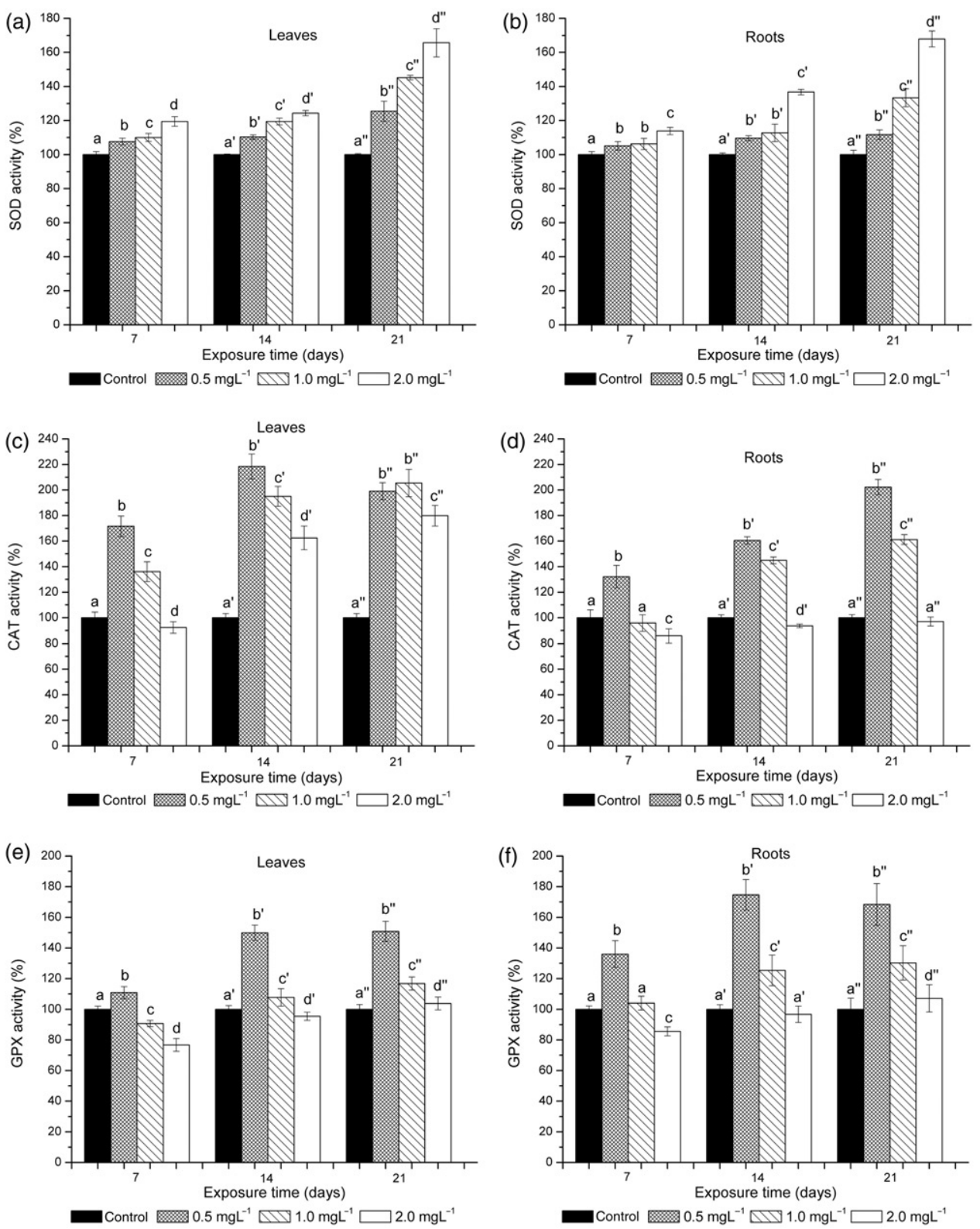

Figure 4. Effects of ibuprofen treatment on the enzymatic activities of the antioxidant enzymes superoxide dismutase (a, b), catalase (c, d) and guaiacol peroxidase (e, f) of Typha spp. Side by side are represented the activities measured in the leaves (left) and in the roots (right). The activity was expressed relative to the activity in control plants $(100 \%)$. Vertical error bars indicate $\pm \mathrm{SD}(n=9)$. For each exposure time, ANOVA significant at $P<0.05$ when compared with control; different letters indicate significantly different values. 
The fact that Typha seemed ultimately able to cope with high amounts of IB in the nutrient solution may be indicating that the expected production of excessive ROIs was to some extent effectively counteracted by the antioxidant enzymatic system. This machinery involves the sequential and simultaneous actions of a number of enzymes including SOD, CAT and peroxidases (POX) as described in Mittler [14].

Upon measurement of the activities of some of these enzymes, an increase in SOD activity was observed in the plants exposed to IB solutions in comparison with that of the control plants. This increase, which was observed both in leaves and roots (Figures 4(a) and $4(\mathrm{~b})$ ), can be attributed to an increase in superoxide radicals within the cells. This enzyme's activity is higher for the highest IB concentration and for the longest exposure time. The continuous increase in SOD activity may be an evidence of the stress caused by the uptake and accumulation of the xenobiotic or its degradation products within the plant tissues leading to the consequent production of superoxide radicals which stimulates the enzymatic response.

The activities of some $\mathrm{H}_{2} \mathrm{O}_{2}$-eliminating enzymes that act in co-operation and in sequence to SOD action, CAT and GPX, are affected in a way which is different from that observed for SOD (Figures 4(c), 4(d), 4(e) and 4(f)). An increase in CAT and GPX activity is observed in leaves and roots of the plants subjected to $0.5 \mathrm{mg} \mathrm{L}^{-1}$ of IB. Top activities of CAT and GPX are attained at this IB concentration, and increasing the concentration beyond $0.5 \mathrm{mg} \mathrm{L}^{-1}$ almost always leads to a diminishing of both enzymes activities when compared to the $0.5 \mathrm{mg} \mathrm{L}^{-1}$ assay. Nevertheless, CAT and GPX activities in plants exposed to $1.0 \mathrm{mg} \mathrm{L}^{-1}$ of IB are in general still higher than those of the control plants. On the other hand, for plants exposed to $2.0 \mathrm{mg} \mathrm{L}^{-1}$ of IB, the activities of these enzymes are in some cases lower than the control activities' levels, which reveals some inhibition induced by IB's presence. CAT and GPX inhibition is also more evident at the 7-day exposure, when IB concentrations in the nutrient solution are higher.

GPX seems to be more affected by increasing amounts of IB in the nutrient solution, as the differences in the enzyme activity between the 0.5 and $1.0 \mathrm{mg} \mathrm{L}^{-1}$ assays are more evident than those observed for the CAT enzyme (see Figure 4(c), 4(d), 4(e) and 4(f)).

The strong induction of CAT and GPX enzyme activity at the lower IB concentration followed by the decrease of the activity at higher IB concentrations suggests that the enzymatic system is failing and IB toxicity is affecting the plant. This observation is in agreement with the observed diminishment in RGR and photosynthetic pigments content in plants grown in the most IB concentrated nutrient solutions.

The trends observed in the enzyme activity alterations are not very different in the roots and in the leaves of the plants exposed to IB, suggesting that both tissues are affected by the xenobiotic. It is also interesting to note that despite the fact that there are only small amounts of IB in the nutrient solution during the third week of assays, the enzyme activity of the plants is still altered when compared to the control and overall presents the same trend observed at 7 and 14 days. This fact is illustrative of the long-term effects caused by IB, which might be an indication that either IB or its degradation products were in fact taken up by the plant roots and, at least, partially translocated.

\section{Conclusion}

The macrophyte Typha spp. was able to remove nearly all IB (>99\%) after 21 days of exposure to a solution spiked with $20 \mu \mathrm{g} \mathrm{L}^{-1}$, with over $58 \%$ being removed just within 
the first $24 \mathrm{~h}$ and over $95 \%$ after $96 \mathrm{~h}$. Even when the plants were subjected to concentrations several orders of magnitude higher, still high IB removal efficiencies were observed. In the tested IB concentrations range, a linear relationship was observed between initial and removed amounts of IB, except in the case where IB toxicity effects become more adverse to Typha $\left(2 \mathrm{mg} \mathrm{L}^{-1}\right)$.

IB removal was achieved without obvious visual symptoms of toxicity. However, by observing the enzymatic response to the abiotic stress induced by IB, an inhibition of enzymes activities could be noted in some cases, especially for the highest concentrations, which may be regarded as an early sign of toxicity along with a diminishment in the photosynthetic pigments contents and an inhibition of Typha's growth (through the decline of the RGR parameter). For the lowest concentrations, however, Typha seemed ultimately able to cope with the exposure to the xenobiotic. In addition, the fact that enzymatic activities were altered both in root and leaf tissues is an indication that the pharmaceutical or intermediate degradation products were taken up by the plants and translocated to aerial parts.

The present results suggest that Typha spp. may indeed have an active role in removing pharmaceuticals from contaminated waters when used as a component of constructed wetlands systems and it displays some potential for an application in phytoremediation technologies.

\section{References}

[1] K. Fent, A.A. Weston, and D. Caminada, Aquat. Toxicol. 76, 122 (2006).

[2] D.S. Aga, Fate of Pharmaceuticals in the Environment and in Water Treatment Systems (CRC Press, Boca Raton, FL, 2008).

[3] K. Onesios, J. Yu, and E. Bouwer, Biodegradation. 20, 441 (2009).

[4] R. Haberl, S. Grego, G. Langergraber, R.H. Kadlec, A.R. Cicalini, S. Martins-Dias, J.M. Novais, S. Aubert, A. Gerth, H. Thomas, and A. Hebner, J. Soil Sediment. 3, 109 (2003).

[5] E. Pilon-Smits, Annu. Rev. Plant Biol. 56, 15 (2005).

[6] A.C. Dietz and J.L. Schnoor, Environ. Health Perspect. 109, 163 (2001).

[7] G. Imfeld, M. Braeckevelt, P. Kuschk, and H.H. Richnow, Chemosphere. 74, 349 (2009).

[8] U. Stottmeister, A. Wiessner, P. Kuschk, U. Kappelmeyer, M. Kästner, O. Bederski, R.A. Müller, and H. Moormann, Biotechnol. Adv. 22, 93 (2003).

[9] W.D. Kong, Y.G. Zhu, Y.C. Liang, J. Zhang, F.A. Smith, and A. Yang, Environ. Pollut. 147, 187 (2007).

[10] C. Huber, B. Bartha, R. Harpaintner, and P. Schroder, Environ. Sci. Pollut. Res. 16, 206 (2009).

[11] V. Matamoros, J. Garcia, and J.M. Bayona, Environ. Sci. Technol. 39, 5449 (2005).

[12] V. Matamoros, A. Caselles-Osorio, J. Garcia, and J.M. Bayona, Sci. Total Environ. 394, 171 (2008).

[13] N. Park, B.J. Vanderford, S.A. Snyder, S. Sarp, S.D. Kim, and J. Sarp, Ecol. Eng. 35, 418 (2009).

[14] R. Mittler, Trends Plant Sci. 7, 405 (2002).

[15] J.N. Miller and J.C. Miller, Statistics and Chemometrics for Analytical Chemistry, 4th ed (Prentice Hall, Harlow, UK, 2000).

[16] N.M. Vieno, T. Tuhkanen, and L. Kronberg, J. Chromatogr. A. 1134, 101 (2006).

[17] A.V. Dordio, C. Duarte, M. Barreiros, A.J.P. Carvalho, A.P. Pinto, and C.T. da Costa, Bioresour. Technol. 100, 1156 (2009).

[18] H.K. Lichtenthaler and A.R. Wellburn, Biochem. Soc. Trans. 11, 591 (1983).

[19] R.J. Porra, Photosynth. Res. 73, 149 (2002). 
[20] A.K. Shanker, M. Djanaguiraman, R. Sudhagar, C.N. Chandrashekar, and G. Pathmanabhan, Plant Sci.. 166, 1035 (2004).

[21] H. Aebi, Methods Enzymol. 105, 121 (1984).

[22] J.M. McCord and I. Fridovich, J. Biol. Chem. 244, 6049 (1969).

[23] H.U. Bergmeyer, Methods of Enzymatic analysis, 3rd ed (Verlag Chemie, Weinheim, Germany, 1983), pp. 273-286.

[24] M. Gros, M. Petrovic, and D. Barceló, Talanta. 70, 678 (2006).

[25] M. Petrovic and D. Barceló, Analysis, Fate and Removal of Pharmaceuticals in the Water Cycle (Elsevier, Amsterdam, The Netherlands, 2007).

[26] A. Amaya-Chávez, L. Martínez-Tabche, E. López-López, and M. Galar-Martínez, Chemosphere. 63, 1124 (2006).

[27] J.L. Santos, I. Aparicio, and E. Alonso, Environ. Int. 33, 596 (2007).

[28] H.W. Sun, J. Xu, S.H. Yang, G.L. Liu, and S.G. Dai, Chemosphere. 54, 569 (2004).

[29] R. Olette, M. Couderchet, S. Biagianti, and P. Eullaffroy, Chemosphere. 70, 1414 (2008).

[30] T. Scheytt, P. Mersmann, R. Lindstadt, and T. Heberer, Water Air Soil Pollut. 165, 3 (2005).

[31] M. Carballa, G. Fink, F. Omil, J.M. Lema, and T. Ternes, Water Res. 42, 287 (2008). 